\title{
A HUMANE LEGAL RESPONSE TO CONTEMPORARY CHALLENGES ON THE USE OF FORCE POSED BY NON-STATE THREATS AND POSSIBLE MISUSES OF MILITARY NECESSITY
}

\author{
Nicolás Carrillo-Santarelli ${ }^{1}$
}

\begin{abstract}
Giving preeminence to military interests over humanitarian considerations in international law may encourage attacks that violate the jus ad bellum because the generation of an armed attack will entitle targeting individuals in order to further the goals of entities carrying out the attacks. If this happens, individuals will be treated as means, and their human dignity will be violated. Thus, attacks on life in the mentioned circumstances violate the foundational value of both human rights and humanitarian law norms. Therefore, in order to discourage resorting to war and tweaking the law, depriving humanitarian guarantees of their effectiveness, a prevalent human rights law approach that acknowledges the arbitrariness and ensuing unlawfulness in those conducts is necessary. International Humanitarian Law can also be understood as violated, but even if it is not considered to be breached, an autonomous understanding of human rights law not subject to IHL is possible. Apart from the previous concerns, there is the issue of non-state uses of force. A State-centered conception of international law is inadequate to answer to reality and protect international legal goods. This is felt in jus ad bellum and jus in bello, because the impact of non-state actors cannot be dealt with properly in its light. In this regard, there are problems concerning the possibility of resorting to self-defense against non-state armed groups located in the territory of another State or in the regulation of armed conflicts in which non-state actors participate. Some of these challenges can be met with existing norms although there are gaps that call for regulation de lege ferenda
\end{abstract}

Keywords: human dignity; right to life; jus ad bellum; jus in bello, non-state actors.

\section{INTRODUCTION}

Currently, with the threat of ISIS and the actions of non-state armed actors, two sets of challenges ensue: firstly, making sure that operations in the territory of third countries against them are necessary and do lead to interpretations of law that could be prone to justify abuses, while also permitting responding to the challenges of such conduct lest individuals are unprotected against them. This paper will examine both sets of issues, arguing for a humane approach and the idea that the principle of human dignity or the pro homine or pro personae considerations must guide every implementation of international law, to demand that no abuses or excessive uses

\footnotetext{
${ }^{1}$ Investigador de Derecho internacional público Universidad Autónoma de Madrid. E-mail: nicolas.carrillos@gmail.com vol.09, nº. 02, Rio de Janeiro, 2016.pp. 980-1011
} 
of lethal force are justified and that no human beings are undefended from non-state serious abuses based on unnecessary interpretations.

\section{APLEA FOR APREVALENT HUMAN RIGHTS LAW APPROACH TO THE RIGHT TO LIFE DURING (UNJUST) ARMED CONFLICTS}

International bodies that examine compliance with the duty to respect the right to life under human rights law in regard to entities bound by it that are accused or suspected of having breached it in times of armed conflicts often resort to considering that the content of the obligation is to be interpreted in the light of the regulations on the possibility of depriving someone of his life found in international humanitarianlaw. ${ }^{2}$

This analysis seems legally correct at first, for two reasons: firstly, because human rights law tends to word the right to life as encompassing the guarantee to not have one's life deprived of arbitrarily, ${ }^{3}$ it is deemed that when a specialized set of norms dealing with the regulation of armed conflicts shed light on when deprivation of life during those conflicts is unlawful, compliance with those norms would make an act of deprivation of life not arbitrary. This reading the human right to life in the light of international humanitarian law would be thus consistent with the criterion of lex specialis, and would help to harmonize different branches of international law. ${ }^{4}$

Additionally, it would seem that the military interests of belligerents during armed conflicts and the special circumstances surrounding these events, may be largely ignored by norms different from those belonging to humanitarian law, that specifically take those elements into account ${ }^{5}$-sometimes overestimating them and giving them exaggerated importance, to the detriment of the protection of individuals, in my opinion-. Thus, the proper regulation of the social phenomenon of armed conflicts from a sociological point of view ${ }^{6}$ would seem to be that found in international humanitarian law (hereinafter, IHL).

Notwithstanding, I hold that even if the previous considerations prove true in some occasions, it is very risky and dangerous to generalize them and to subject the human rights law regulation of the right to life to

\footnotetext{
${ }^{2}$ See International Court of Justice, Legality of the Threat or Use of Nuclear Weapons, Advisory Opinion, 8 July 1996, para. 25; Inter-American Commission on Human Rights, Report No. 112/10, Inter-State Petition IP-02, Admissibility, Franklin Guillermo Aisalla Molina, Ecuador - Colombia, 21 October 2010, para. 122.

${ }^{3}$ See, inter alia, Human Rights Committee, Article 6 (Right to life), General comment No. 6, Sixteenth session, 1982, para. 3; articles 6.1 of the International Covenant on Civil and Political Rights, 4.1 of the American Convention on Human Rights, and 4 of the African Charter on Human and Peoples' Rights.

${ }^{4}$ See International Law Commission, "Conclusions of the work of the Study Group on the Fragmentation of International Law: Difficulties arising from the Diversification and Expansion of International Law”, 58 $8^{\text {th }}$ session, 2006, A/61/10, Section 2, Conclusions 5 through 10.

${ }^{5}$ See Frits Kalshoven and Liesbeth Zegveld, Constraints on the Waging of War, an Introduction to International Humanitarian Law, ICRC, 2001, at 16, 37-38, 203-204; article 51.5.b of the Protocol Additional to the Geneva Conventions of 12 August 1949 , and relating to the Protection of Victims of International Armed Conflicts (Protocol 1), among others.

${ }^{6}$ In accordance to the maxim of sic societas sicut jus, law should take into account social features in order to properly regulate them, because every society needs a particular law. On this, see Antonio Remiro Brotóns, Derecho Internacional, Tirant Lo Blanch, 2007, at 46.
} _vol.09, nº. 22, Rio de Janeiro, 2016.pp.980-1011 
humanitarian law considerations unconditionally and generally. In fact, as will be explained below, such automatic subjection is not absolute, and other modes of interplay between human rights law and IHL are possible and required, depending on the circumstances.

Furthermore, an absolute and automatic dependence of the human right to life on the regulation of armed conflicts could lead to abuses and to depriving that right of its purpose and guarantees, for the following reason: given the fact that most authors agree that the jus in bello is autonomous from the jus ad bellum, it is possible for example that a State that has the intention of killing a foreigner with military functions will carry out an act of aggression against another State and, by entering into an armed conflict with the latter if it defends itself with arms, will be automatically entitled to target enemy combatants, among which naturally members of the armed forces and thus the previously selected foreigner are included. ${ }^{8}$ Thus, the State will commit an unlawful act in order to obtain the legal entitlement to carry out a murder that would be otherwise unlawful.

The reasons why a State or non-state actor capable of carrying out armed attacks may desire to engage in such a conduct are manifold, but among them one can think of the design to attack persons regarded as acting contrary to their interests, or of the design to support a given side to a civil conflict by means of entering into it, even unlawfully, in order to be entitled to attack the other side and prominent figures in it, including leaders that may be considered combatants and they desire to beremoved.

It may be said that the independent regulation of jus in bello is necessary in order to not criminalize all or most military actions of armed forces during armed conflicts, and that in the case with which I illustrated my point the aggressor State would nonetheless have its responsibility engaged as a result of the breach of the prohibition of the use of force to it, duty that has autonomy.

Even if this proves to be true, a fact remains: in cases as that of the example, a human being, or many individuals, will be treated as mere ends by the State, which is contrary to the Kantian consideration that given their dignity individuals are ends in themselves and not means for others to achieve their goals ${ }^{9}$ : having no a priori legal entitlement to attack some individuals, a State may well regard them as undesirable and attack them to

\footnotetext{
${ }^{7}$ See Frits Kalshoven and Liesbeth Zegveld, op. cit., at 84. Moreover, the difference between the crime of aggression and war crimes seems to reinforce the distinction between jus ad bellum and jus in bello. This difference can be found in article 5 of the Rome Statute of the International Criminal Court, Principle VI of the Principles of International Law Recognized in the Charter of the Nuremberg Tribunal, or in Article 6 of the Charter of the International Military Tribunal - Annex to the Agreement for the prosecution and punishment of the major war criminals of the European Axis ("London Agreement).

${ }^{8}$ See Interpretive Guidance on the Notion of Direct Participation in Hostilities under International Humanitarian Law, ICRC, 2009 , at 20,27.

9 See Andrew Clapham, Human Rights: a Very Short Introduction, Oxford University Press, 2007, at 22; Andrew Clapham, Human Rights Obligations of Non-State Actors, Oxford University Press, 2006, at535-548.
} 
achieve its goals, thus disregard their human dignity, that according to the human rights philosophy constitutes the inner worth of everyindividual, even of those accused of violating the rights of others. ${ }^{10}$

What must not be forgotten is that human dignity constitutes the foundation of human rights law. ${ }^{11}$ Therefore, I sustain that acts contrary to it should be considered as unlawful for human rights law, even if they are permitted by other branches of international law. Furthermore, the fact that human rights law is applicable both in times of peace and during armed conflicts ${ }^{12}$ presupposes that it cannot be disregarded during the latter, and thus acts that imply the intentional causation of death of individuals that violate their dignity, even if they take place during armed conflicts, are contrary to human rightslaw.

What is more, however, is that human dignity also informs several norms of international humanitarian law, as has been acknowledged by doctrine and the Inter-American Commission on Human Rights, that went as far as saying that human rights law and IHL share some common rights and norms precisely given their protection of human dignity, by saying that

"In common with other universal and regional human rights instruments, the American Convention and the 1949 Geneva Conventions share a common core of non-derogable rights and the mutual goal of protecting the physical integrity and dignity inherent in the human being.". ${ }^{13}$

Thus, one has to wonder whether IHL is not also subject to human rights law in turn or, if not, at least to the respect of human dignity: it certainlyis.

\footnotetext{
${ }^{10}$ Mentions of the inalienability of some rights are found in the Preambles to the Universal Declaration of Human Rights and to the two Covenants on Human Rights adopted in 1966 -on Civil and Political Rights and on Economic, Social and Cultural Rights-. On the elements of the non-relational/non-conditional character of dignity-based rights, their inalienability and inherent character, that makes them belong to every human being for the mere fact of being such, see Jack Donnelly, "Human Rights and Human Dignity: Ana Analytic Critique of Non-Western Conceptions of Human Rights", The American Political Science Review, Vol. 76, 1982, pp. 305-307, 310; Oscar Schachter, "Human Dignity as a Normative Concept", The American Journal of International Law, Vol. 77, 1983, pp. 849, 853; Oliver Sensen, "Human Dignity in Historical Perspective: The Contemporary and Traditional Paradigms", European Journal of Political Theory, Vol. 10, 2011; Andrew Clapham, Human Rights: a Very Short Introduction, op. cit., at 16, 33, 39, 45; Inter-American Commission on Human Rights, Report No. 112/10, Inter-State Petition IP-02, Admissibility, Franklin Guillermo Aisalla Molina, Ecuador - Colombia, 21 October 2010, para. 91; Inter-American Commission on Human Rights, Report on Terrorism and Human Rights, OEA/Ser.L/V/II.116, 22 October 2002, para. 5, where it is mentioned that "efforts to oppose terrorism and the protection of human rights and democracy are not antithetical responsibilities"; InterAmerican Court of Human Rights, Case of Castillo Petruzzi et al. v. Peru, Judgment of 30 May 1999, para. 89; Resolution 41/120 of the General Assembly of the United Nations.

${ }^{11}$ See Carlos Villán Durán, Curso de Derecho Internacional de los Derechos Humanos, Trotta, 2006, pp. 63, 92; the Preamble and Articles 1, 22 and 23 of the Universal Declaration of Human Rights; Resolution 41/120 of the General Assembly; Helsinki Final Act of 1 August 1975 of the Conference on Security and Co-Operation in Europe; Rafael Domingo, $i$ Qué es el derecho global?, Thomson Aranzadi, 2007, at 88, 142; Preamble to the Vienna Declaration and Programme of Action of the World Conference on Human Rights of 1993.

${ }^{12}$ See International Court of Justice, Legal Consequences of the Construction of a Wall in the Occupied Palestinian Territory, Advisory Opinion, 9 July 2004, para. 106; International Court of Justice, Legality of the Threat or Use of Nuclear Weapons, Advisory Opinion, 8 July 1996, para. 25; Hans-Joachim Heintze, "On the relationship between human rights law protection and international humanitarian law", International Review of the Red Cross, No. 856, 2004. Additionally, it has been said that "everyone is entitled to the enjoyment of human rights, whether in time of peace or war", as commented in Office of the High Commissioner forHuman Rights, FactSheetNo. 13, InternationalHumanitarianLawandHumanRights.

${ }^{13}$ See Inter-American Commission on Human Rights, Report No. 112/10, Inter-State Petition IP-02, Admissibility, Franklin Guillermo Aisalla Molina, Ecuador-Colombia, 21 October 2010, para. 117.
} 


\section{The background of the problem: the remnants of an armamentistic legal mindset and $i$ ts gradual superation}

The current regulation of the prohibition of the use of force constitutes a fairly recent legal victory and achievement for those who are concerned with the necessity of deterring war and fostering peace, given the suffering of human beings intimately linked with armed conflicts. In this regard, as a product of awareness of the tragedy of World War II and weak and insufficient normative antecedents, ${ }^{14}$ articles 2 and 51 of the Charter of the United Nations stand apart from a long tradition of rules regarding resort to the use of force as a permissible option in inter-State relations. ${ }^{15}$

Even if challenged by some, ${ }^{16}$ it is considered that peace is best guaranteed by permitting force only when it is necessary for a State to defend itself against a major use of force or when a multi-lateral decision in that regard that complies with the requirements of necessity and proportionality has been made. If something can be outrightly criticized about the existing framework is its reliance on a politicized and often hypocrite and abusive body, also known as the Security Council, that permits its permanent members to shield themselves and their accomplices (also known as allies) as a result of the power of veto they enjoy.

Even if references to some "just wars" of the past that do not conform with today's standards have been overcome in theory, in practice the norms that regulate the use of force may still be violated or manipulated, that is to say, States may try to violate them and pretend to comply with them by arguing that they are either engaging in self-defense or following an authorization by the Security Council when in fact they ignore the exact scope of its authorization or are not faced with a true threat in the form of a major use of force against them.

Additionally, the militaristic mindset that prevailed prior to 1945 is still ingrained in and still pervades somewhat in some norms. In fact, the almost unlimited "license to kill" given to combatants in international armed conflicts by IHL, that yet prohibits direct and indiscriminate attacks against civilians, disproportionate civilian casualties or the lack of precautionary measures to spare civilian lives, ${ }^{17}$ is witness to the consideration that military needs are to be taken into account by internationallaw.

This mould, however, is broken when it comes to non-international armed conflicts, and it is so because the prisoner of war status and the combatant privileges are not automatically present in them, and because those

\footnotetext{
${ }^{14}$ See Antonio Remiro Brotóns et al, Derecho Internacional, curso general, Tirant Lo Blanch, 2010, at 665-666.

${ }^{15} \mathrm{Ibid}$.

${ }^{16}$ See A more secure world: Our shared responsibility, Report of the High-level Panel on Threats, Challenges and Change, United Nations, 2004, paras. 188-192.

${ }^{17}$ See, among others, Jean-Marie Henckaerts and Louise Doswald-Beck, Customary International Humanitarian Law, Volume I: Rules, Cambridge University Press - ICRC, 2009, Part I (the Principle of Distinction), Rules 1 through 24.
} 
who participate in hostilities may be tried and punished precisely for that participation, even if they do not commit war crimes or other international crimes. ${ }^{18}$

This regulation can be seen by some as the result of the consideration that in civilwars the inhabitants of a State must comply with that State's domestic law, that may outlaw the activities combatants engage in, especially when carried out against State forces. However, as regulated in humanitarian law treaties, and as considered by the International Committee of the Red Cross and authors such as Marko Milanovic, non-international armed conflicts include but are not limited to "civil wars", encompassing also armed conflicts between non-state actors or "transnational" armed conflicts, which are those in which the conflict surpasses the territory of a given State but where States do not confront each other. ${ }^{19}$ As a digression, it must be mentioned that it is perfectly possible that reality surpasses regulation, and that some conflicts are partly regulated as international and partly as noninternational, depending on the relationships beingregulated.

As a result of the multiple possibilities of non-international armed conflicts, saying that the differences regarding the acts permitted to combatants in international armed conflicts and non-international ones are explained because of the particular circumstances of "civil wars" cannot be sustained. As expected, abuses may be committed because of this absence of regulation in non-international armed conflicts and controversies may arise: rebels may criticize that they are punished while State agents are not, and in today's sad world captured alleged "terrorists" can receive a treatment that is different from (and possibly worse or as bad as) that expected to be given to State soldiers. As a result, I hold that human rights law must inform IHL in these cases: it constitutes a corpus juris with which to examine the legality of the treatment of combatants, being it necessary to respect the principle of legality, their right to a due process, and their right to life, among others. Likewise, these rights can serve a basis for the regulation of their conduct.

In consequence, for example, those who engage in hostilities against democratic regimes may be perfectly charged with murder for killing State agents, having thus a duty to seek to advance their ideas in accordance with the rule of law, but simultaneously captured rebels must be respected in their rights -some of

\footnotetext{
${ }^{18}$ See Interpretive Guidance on the Notion of Direct Participation in Hostilities under International Humanitarian Law, op.cit.,at 33; Jean-Marie Henckaerts and Louise Doswald-Beck, op. cit., at 395 ("no right to [prisoner-of-war] status exists in [noninternational armed conflicts]”).

${ }^{19}$ See Marko Milanovic, 'Lessons for human rights and humanitarian law in the war on terror: comparing Hamdan and the Israeli Targeted Killings case', 89 International Review of the Red Cross, No. 866 (2007), at 381; common article 3 of the Geneva Conventions of 1949 in comparison with article 1 of Protocol II Additional to the to the aforementioned Conventions and relating to the Protection of Victims of Non-International Armed Conflicts. Likewise, see the commentary to Paragraph 1 of article 1 of Protocol II made by the ICRC, found on: http:/ / www.icrc.org/ihl.nsf/COM/475-760004?OpenDocument
} 
which may be legitimately suspended in their enjoyment temporarily, proportionately and when necessary, as clauses in human rights treaties envisage ${ }^{20}$.

Can such a rationale not be transplanted to the regulation of international armed conflicts? I think that it is perfectly possible, especially because domestic and international courts, alongside international human rights bodies, have declared that there are occasions in which international human rights law constitutes lex specialis and prevails over IHL and, in consequence, over the military considerations found there.

These events in which human rights law remains autonomous, prevails and can even inform the interpretation of IHL can be summarized as follows: (i) when hostilities are not actually conducted, even if they take place in a zone ravaged by war, autonomous human rights considerations prevail; ${ }^{21}$ (ii) when human rights law offers more detailed guidelines and regulations, and examines more in detail some acts (lex specialis consideration strictly speaking); ${ }^{22}$ and (iii) when IHL is limited by human rights law, by means of having to respect its tenets and be interpreted in its light, in order to offer a more robust protection of human dignity given the possibility of human dignity being unprotected if human rights considerations are not taken into account, ${ }^{23}$ relevant datum because dignity is a foundational value both branches share.

In consequence, it is admissible to say that human rights considerations can also limit or, for a better choice of words, illuminate international humanitarian regulations. If this is possible generally, then nothing prevents this from being applicable in regard to the right to life, also enjoyed by combatants.

In my opinion, when States or armed groups - equally capable of this- resort to aggression and major uses of force in a manner contrary to the prohibition of the use of force ${ }^{24}$, the State has no entitlement to carry out armed operations and this unlawfulness should taint the acts that follow, including attacks against combatants of

\footnotetext{
${ }^{20}$ See articles 4 of the International Covenant on Civil and Political Rights, 27 of the American Convention on Human Rights, or 15 of the European Convention for the Protection of Human Rights and Fundamental Freedoms; International Court of Justice, Legality of the Threator Use of Nuclear Weapons, Advisory Opinion, 8 July 1996, para. 25.

${ }^{21}$ See Report of the Special Rapporteur on extrajudicial, summary or arbitrary executions, Philip Alston, Addendum, Study on Targeted Killings, A/HRC/14/24/Add.6, 28 May 2010, para. 29, footnote 53.

${ }^{22}$ See Inter-American Commission on Human Rights, Report No. 112/10, Inter-State Petition IP-02, Admissibility, Franklin Guillermo Aisalla Molina, Ecuador - Colombia, 21 October 2010, par. 121; Marko Milanovic, op. cit., at 391.

${ }^{23}$ See Marko Milanovic, op. cit., at390-392.

${ }^{24}$ In this regard, let it be said that The General Assembly and the International Court of Justice recognized that non-state actors are capable of conducting attacks that have the same intensity of major uses of force, implicitly recognizing that they are able to commit minor uses of force as well. This is seen in: International Court of Justice, Case concerning Military and Paramilitary Activities in and Against Nicaragua, Nicaragua v. United States of America, Judgment of 27 June 1986 (Merits), par. 195; article 3.g of Resolution 3314 (XXIX) of the General Assembly of the United Nations. Furthermore, the existence of a right of self-defense against major uses of force attributable to non-state actors is evinced by Security Council Resolutions 1368 (2001) and 1373 (2001), that allude to one such right. On this, see: Preambles to SC Res. 1368 (2001) and SC Res. 1373 (2001); Report of the Special Rapporteur on extrajudicial, summary or arbitrary executions, Philip Alston, Addendum, Study on Targeted Killings, A/HRC/14/24/Add.6, 28 May 2010, para. 40 (in which it is considered that Security Council authorization to use "extraterritorial force" against non-state actors isnecessary).
} 
the offended State, just as evidence obtained by human rights abuses cannot be employed against the victims of these abuses.

If my argument is received, soldiers and subordinates in the armed forces of States and non-state actors are to strive to ascertain whether they are ordered to take part in an illegal armed attack and the ensuing operations. That they must make this type of examination with due diligence is warranted by case-law and treatylaw, according to which even subordinates must not follow orders contrary to international law, in particular to human rights law, humanitarian law, or international criminal law. ${ }^{25}$ Thus, those soldiers or agents must refrain from participating in hostilities, and are under a duty to do so and point out the potential additional unlawful acts to their superiors.

It will be noticed that my proposal entails blurring the divisions between the jus ad bellum and the jus in bello. I am aware of that and defend that blurring, because the artificial absolute separation may lead to the legal endorsement of abuses. In fact, analyzed globally, attacks carried out after an unlawful use of force are part of the same design or global operation, and just as it has been considered that human rights law demands examining elements of due process such as reasonable periods of time globally, ${ }^{26}$ an artificial separation that ignores to whole scenario may condone aggressive States and end up legitimizing the achievements of the strong when they succeed in their purports. The legal community must be told that violations of the right to life have taken place, to defend the victims of victim States or armed groups that face aggression and can do nothing but try to defend theirs.

But for the sake of discussion, let it be considered that the possibility of a combatant being deprived of his life under IHL exists even when his life is taken by a combatant belonging to a party that has breached jus ad bellum but complies with IHL norms. Even then, I hold, that act is unlawful, if not under IHL - which according to this alternative analysis would not be limited by human rights law-, then by all means by international human rights law, if it is analyzed autonomously and not conditioned to and subjected to militaristic notions ingrained in IHL.

The necessity of this approach is made clear by a recent opinion of the International Committee of the Red Cross, according to which the rules of international armed conflicts apply when a State attacks a non-state actor in the territory of a third State which has not authorized such attack. The rationale of the ICRC is the provision of greater guarantees, so as to make sure that the attacking State is aware of its duties to refrain from

\footnotetext{
${ }^{25}$ See European Court of Human Rights, Grand Chamber, Case of Kononov v. Latvia, Judgment, 17 May 2010, para. 236; article 33 of the Rome Statute of the International Criminal Court; Judgment of the International Military Tribunal for the Trial of German Major War Criminals, where it is mentioned that "the very essence of the Charter is that individuals have international duties which transcend the national obligations of obedience imposed by the individual State. He who violates the laws of war cannot obtain immunity while acting in pursuance of the authority of the State if the State in authorising action moves outside its competence under internationallaw."

${ }^{26}$ See Inter-American Court of Human Rights, Case of Genie-Lacayo v. Nicaragua,Judgment, 29 January 1997, para. 81.
} _vol.09, nº. 02, Rio de Janeiro, 2016.pp. 980-1011 
attacking the civilian persons and objects in the territorial State. ${ }^{27}$ That being said, there is a risk of abuse in case the attacking State regards that the application of IHL rules allows it to attack combatants of the territorial State. To prevent this, two principles must be employed: the prohibition of the abuse of rights, ${ }^{28}$ which would indicate that attacking combatants of the territorial State is unlawful when self-defence is directed against a non-state group located therein; and human rights law as lex specialis, since such killings of State combatants would be arbitrary and thus contrary to the right to life, being unnecessary and motivated by a circumstance created by the invading State.

\section{Human Rights protection of the dignity of combatants of vic tims of aggression}

At the outset I mentioned how human rights law prohibits arbitrary deprivations of life, and accordingly protects individuals against them. Traditionally, it is understood that prima facie acts that are respectful of international humanitarian law could not be called arbitrary although, as mentioned in the previous section, they may be suspicious or prone to criticism, even from a legalstandpoint.

Even if we assume that the IHL regulation remains unaffected by jus ad bellum considerations, and if we thought that human rights law does not impose additional burdens and conditions to the possibility of depriving combatants of their lives under that regime, I sustain that given the greater guarantees of human rights law it should, if it does not condition and illuminate IHL, at least remain independent, just as jus ad bellum and jus in bello would be independent if we followed this train of thoughts analyzed for the sake of exploring all the possibilities. This would be so because otherwise IHL would impede the human rights protection of dignity in regard to the right to life and, as has been commented by Philip Alston, "Human rights law and IHL apply coextensively and simultaneously unless there is a conflict between them ${ }^{29}$ (emphasis added), being the conflict the contradiction between the protection of human dignity offered in human rights law and militaristic IHL regulations that do not envisage preventing making some individuals being treated as objects by others, that therefore would be treated in a manner contrary to their human dignity, foundational value of human rights law (and some IHL norms, it must not be forgotten).

Therefore, IHL and human rights law can also be autonomous. The International Court of Justice has considered that when they do not intersect and regulate different aspects, IHL and human rights law enjoy this

\footnotetext{
${ }^{27}$ See Adil Ahmad Haque, "The United States is at War with Syria (according to the ICRC's New Geneva Convention Commentary), EJIL: Talk!, 8 April 2016, available at: http://www.ejiltalk.org/the-united-states-is-at-war-with-syria-according-tothe-icrcs-new-geneva-convention-commentary/comment-page-1/\#comment-242663 (last checked: 13 April 2016).

${ }^{28}$ Michael Byers, "Abuse of Rights: An Old Principle, A New Age”, McGill Law Journal,Vol. 47, 2002.

${ }^{29}$ See Report of the Special Rapporteur on extrajudicial, summary or arbitrary executions, Philip Alston, Addendum, Study on Targeted Killings, A/HRC/14/24/Add.6, 28 May 2010, para. 29, footnote53.
} 
autonomy. ${ }^{30}$ I go one step further: if it is considered that IHL does not accommodate guarantees of dignity under human rights law that the latter cannot renounce to, human rights must strive to achieve their goals and protect human dignity, likewise repelling IHL influences that seek to deprive this protection of human dignity in the form of the right to life of its purpose, as would happen when individuals are used as means by others. Concerning this, the International Law Commission has mentioned that the criterion of lex specialis is not applicable if is application "might frustrate the purpose of the general law"31.

Under human rights law norms, it is considered that States have not only a duty to refrain from violating the right to life but also to positively protect it, and that this right enshrines a supreme value and has a special strength. Flowing from these considerations, the Human Rights Committee has argued that given the threat to life and frequent deaths during armed conflicts,

Efforts "to avert the danger of war $[\ldots]$ and to strengthen international peace and security would constitute the most important condition and guarantee for safeguarding the right to life." 32

Because of this, the Committee has also said that:

"[I]t is the supreme duty of States to prevent wars. War and other acts of mass violence continue to be a scourge of humanity and take the lives of thousands of innocent human beings every year. ${ }^{\text {"33 }}$

In consequence, when States or non-state actors breach the prohibition of the use of force, they are creating the risk of deprivations of life from individuals in the victim attacked entity, including their security forces, that should not bear the burden of combating and risking their own lives, risk that increases if they are considered legitimate targets.

According to human rights case-law, States that create a risk to human rights are under special stringent duties to behave with more than due diligence in order to prevent that risk from materializing, ${ }^{34}$ and I consider that this rationale, based on the need of protecting human beings from irresponsible behavior, can be extended to risks generated by non-state actors as well. In the case being examined, the risk created by violations of the prohibition of the use of force is undeniable, and thus security agents of the offender, that can engage the liability of the entity they represent, should refrain from engaging in hostilities.

\footnotetext{
${ }^{30}$ The ICJ considered that "As regards the relationship between international humanitarian law and human rights law, there are thus three possible situations: some rights may be exclusively matters of international humanitarian law; others may be exclusively matters of human rights law; yet others may be matters of both these branches of international law. In order to answer the question put to it, the Court will have to take into consideration both these branches of international law, namely human rights law and, as lex specialis, international humanitarian law" (emphasis added), in: International Court of Justice, Legal Consequences of the Construction ofa Wallin the OccupiedPalestinian Territory,Advisory Opinion,9July2004para. 106.

${ }^{31}$ See International Law Commission, "Conclusions of the work of the Study Group on the Fragmentation of International Law: Difficulties arising from the Diversification and Expansion of International Law”, 58 ${ }^{\text {th }}$ session, 2006, A/61/10, Conclusion 10.

${ }^{32}$ See Human Rights Committee, Article 6 (Right to life), General comment No. 6, Sixteenth session, 1982, para. 2.

${ }^{33}$ See Human Rights Committee, Article 6 (Right to life), General comment No. 14, Twenty-third session, 1984, para. 2.

${ }^{34}$ See Inter-American Court of Human Rights, Case of the Pueblo Bello Massacre v. Colombia, Judgment, 31 January 2006 (Merits, Reparations and Costs), paras. 125-126.
} 
The argument that deprivations of life committed by agents of a violator of the jus ad bellum are contrary to human rights law is reinforced by another consideration: the legal principle of ex iniuriajus non oritur prohibits the generation of legal benefits or entitlements as a result of unlawful acts. The principle of the prohibition of the abus de droit, that protects interests of the international community (such as peace and security and the protection of human dignity) may also be invoked. ${ }^{35}$ Analyzed globally, thereby, an operation that is initially aggressive cannot constitute the source of legal shields in jus in bello that have their origin in a violation in the jus ad bellum offered to the entities to which that operation is attributable. Ergo, they ought not to be entitled with the permission to kill agents of an entity that is the victim of an act ofaggression.

General principles of law such as the ones just examined have been employed by human rights bodies and international courts -this is the case of the principles of the pro homine/pro personae protection, or the principle of effectiveness, among others ${ }^{-36}$, and thus mention of the principles that prohibit deriving benefits from wrongful acts or from manipulation of the law in order to deprive it of its purpose and effectiveness is highly pertinent, especially when employed in conjunction with the rule to dispel interpretative uncertainties in order to obtain the goal of human rights law, criterion that is envisaged by the rules of interpretation of international law, ${ }^{37}$ and when considering what the position of general principles of law in the international legal systemis ${ }^{38}$.

The principles being studied, if employed correctly, can serve to dispel the fears of those that consider that the hands of military agents are tied even if conditions change, ever since attacks against enemy combatants may be permitted after a mutation in the general context, in which say after withdrawing from their aggression the original aggressors are attacked and have a right to self-defense, or in which another army can be attacked due to a multi-lateral authorization that emerges later or because new facts make armed operations fall under the scope of

\footnotetext{
${ }^{35}$ Regarding the two cited principles, see Allan Gerson, "Trustee-Occupant: The Legal Status of Israel's presence in the West Bank", Harvard International Law Journal, Vol. 14, 1973, at 5; Separate Opinion of Judge Ammoun to the Judgment of the International Court of Justice of 5 February 1970 in the Case concerning the Barcelona Traction, Light and Power Company, Limited, at pp. 297, 325, paras. 7, 32. Additionally, see the quote of H. Lauterpacht found in Michael Byers, "Abuse of Rights: An Old Principle, A New Age”, Mc Gill LawJournal,Vol.47,2002, at 391, footnote2.

${ }^{36}$ See, among others, Álvaro Francisco Amaya-Villareal, "El principio pro homine: interpretación extensiva vs. el consentimiento del Estado”, International Law: Revista Colombiana de Derecho Internacional, 2005; Joint Dissenting Opinion of President Owada, Judges Simma, Abraham and Donoghue and Judge ad hoc Gaja to the Preliminary Objections Judgment of the International Court of Justice of 1 April 2011 in the Case concerning Application of the International Convention on the Elimination of all Forms of RacialDiscrimination (Georgia v. Russian Federation), para. 22; Inter-American Court of Human Rights, Case of BaenaRicardo et al. v Panama, Competence Judgment, 28 November 2003, paras. 66-67; Inter-American Court of Human Rights, Case of Ivcher-Bronstein v Peru, Judgment, 6 February 2001, paras. 135-137; Inter-American Court of Human Rights, Case of Las Palmeras v Colombia,Judgment, 6 December 2001, paras. 58,60.

${ }^{37}$ See article 31 of the Vienna Conventions on the Law of Treaties of 1969 and 1986.

${ }^{38}$ See for instance, the idea that resorting to general principles can open a gate to certain criteria that may lead to certain legal outcomes, as discussed in: Philip C. Jessup, Transnational Law, Yale University Press, 1956, at 77. Additionally, see "Conclusions of the work of the Study Group on the Fragmentation on International Law: Difficulties arising from the Diversification and Expansion of International Law", op. cit., sections (1), (5), (18), (19), (20), (31), and (42), where the value of legal principles when attempting to apply and interpret the multiple international legal norms is acknowledged, recognizing that principles are not hierarchically inferior to other sources of international law, and that their usefulness is not limited to gap-filling.
} _vol.09, no. 02, Rio de Janeiro, 2016.pp. 980-1011 
original authorizations issued initially, for instance. As a result, if it is not originally necessary to carry out attacks to protect a civilian population but it later it is, and authorization in that regard exists, then attacks against enemy combatants will not be contrary to the right tolife.

Any doubts in regard to the proposals included herein must be solved following the criterion of the pro homine protection which, besides mandating choosing the norm that most benefits an individual in the protection of her dignity, ${ }^{39}$ must in my opinion include the mandate to choose the interpretation that benefits that protection the most.

To my mind, any doubts and uncertainties will be related to the general context of interpretation but not to the fact that life is better protected if not threatened. It can be said that the life of soldiers is at risk if they do not confront enemy combatants: surely, this can be solved if they withdraw from combat altogether. I acknowledge that there are difficult cases, such as when civilian populations are at risk, but in that regard the Security Council has a duty towards that population, given the connections between peace and security and human rights ${ }^{40}$ and its role as the sole possible entity that can authorize intervention, whereas home States have a duty to protect populations because of their responsibility to protect. ${ }^{41}$ Moreover, the prohibition of the use of force, that includes the only authorized exceptions of self-defense and Security Council authorization within its content, forms part of peremptory law, ${ }^{42}$ and hence admits no exception whatsoever, including contrary interpretations ornorms.

Let it be further said that human rights violations can be established to happen without having to study the subjective component of awareness or intention, ${ }^{43}$ and that thus acts of aggression cannot condone deprivations of life even if soldiers believe that due to (blind) patriotism and the honor and "respectability" of their State they must follow it due to the inappropriateness of international law. The Military Tribunal for the Trial of German Major War Criminals made it clear that these arguments do not work under international law, and this

\footnotetext{
${ }^{39}$ See articles 5 of the International Covenant on Civil and Political Rights, 5 of the International Covenant on Economic, Social and Cultural Rights, 29 of the American Convention on Human Rights, or 53 of the European Convention for the Protection of Human Rights and Fundamental Freedoms.

${ }^{40}$ See Stephan Hobe, "Individuals and Groups as Global Actors: The Denationalization of International Transactions", in Rainer Hofmann (ed.), Non-State Actors as New Subjects of International Law, Duncker \& Humblot (ed.), 1999, at 121-122-

${ }^{41}$ See A more secure world: Our shared responsibility, Report of the High-level Panel on Threats, Challenges and Change, United Nations, 2004, paras. 36, 201,203.

${ }^{42}$ See Antonio Gómez Robledo, Ellus Cogens Internacional: Estudiohistórico-crítico(2003), at 156-157, 159-160, 167.

${ }^{43}$ See Inter-American Court of Human Rights, Case of Velásquez-Rodríguez v. Honduras, Judgment, 29 July 1988, para. 173, where the Court said that "[v]iolations of the Convention cannot be founded upon rules that take psychological factors into account in establishing individual culpability. For the purposes of analysis, the intent or motivation of the agent who has violated the rights recognized by the Convention is irrelevant -- the violation can be established even if the identity of the individual perpetrator is unknown. What is decisive is whether a violation of the rights recognized by the Convention has occurred with the support or the acquiescence of the government, or whether the State has allowed the act to take place without taking measures to prevent it or to punish those responsible. Thus, the Court's task is to determine whether the violation is the result of a State's failure to fulfill its duty to respect and guarantee thoserights".
} 
rests on the fact that no domestic legal arguments can be employed to elude complying with international norms or to invoke absence of responsibility for having breached it. ${ }^{44}$

Arbitrariness can be understood, among others, as basing one's behavior on his own whims or preferences, or as acting unlimited by and disdainful of law and regulations. ${ }^{45}$ For the reasons explained thus far, it is risky to prize States or non-state actors that engage in unlawful uses of force by permitting them to manipulate the law, use others as means to satisfy their interests, and having things their way. We would ignore that the loss of a single life is a very serious thing, and that war and armed conflicts are to be deterred and discouraged as most as possible: certainly, admitting that potential violations of the right to life are at stake may suit this purpose and raise awareness about the need of the international community to strive to protect individuals in all situations, in accordance with the universality of human rights protection, that is not only cultural but against all possible threats. ${ }^{46}$ Let it be reminded just once more that the right to life prohibits arbitrary deprivations of life for the sake of protecting human dignity.

All in all, regardless of whether IHL is to be limited by and interpreted in the light of human rights law in regard to the right to life, it is out of the question that in human rights law the duty to protect and refrain from threatening the life of human beings is not only applicable both during peace and armed conflicts, but also binds combatants. In this regard, the Human Rights Committee has considered that "States $[\ldots]$ should $[\ldots]$ prevent arbitrary killing by their own security forces" ${ }^{37}$ which is consistent with the fact that every agent of the State must comply with the international obligations of his State because any of them can engage its responsibility. ${ }^{48}$ Therefore, in the light of the arguments put forth thus far, under human rights law deprivations of life that are committed in the course of illegitimate recourses to force (violations of the jus ad bellum) are arbitrary and thereby constitute violations of the human right tolife.

I consider that on top of this, those acts are additionally violations of IHL, ever since it should be read in the light of human rights law, that has more complete and robust guarantees and better embodies the legal goal of

\footnotetext{
${ }^{44}$ See articles 27 and 46 of the Vienna Convention on the Law of Treaties and 32 of the Articles on the Responsibility of States for Internationally Wrongful Acts issued by the International Law Commission; International Tribunal for the Prosecution of Persons Responsible for Serious Violations of International Humanitarian Law Committed in the Territory of the Former Yugoslavia since 1991, Prosecutor v. Anto Furundzija,Judgment, 10 December 1998, paras. 155-156, where additional effects when international jus cogens norms are involved are discussed.

${ }^{45}$ See http://dictionary.reference.com/browse/arbitrary;http://www.thefreedictionary.com/arbitrary

${ }^{46}$ Regarding this idea, see Nicolás Carrillo, Enhanced Multi-Level Protection of Human Dignity in a Globalized Context through Humanitarian Global Legal Goods, paper presented in the International Studies Association Annual Convention of 2011 in Montreal, at 21-22, available on: http://papers.ssrn.com/sol3/papers.cfm?abstract_id=1753036

${ }^{47}$ See Human Rights Committee, Article 6 (Right to life), General comment No. 6, Sixteenth session, 1982, para. 3.

${ }^{48}$ See article 4 of the Articles on the Responsibility of States for Internationally Wrongful Acts, issued by the International Law Commission in 2001, where it is said that "The conduct of any State organ shall be considered an act of that State under international law, whether the organ exercises legislative, executive, judicial or any other functions, whatever position it holds in the organization of the State, and whatever its character as an organ of the central Government or of a territorial unit of the State [... ] An organ includes any person or entity which has that status in accordance with the internal law of the State" (emphasis added).
} 
the protection of human dignity, shared by both sets of norms. If this is not accepted, then, even if IHL would be respected in the aforementioned circumstances, there would be a violation of human rights law, because if it is considered to be prevalent (conditioning IHL) or autonomous (preserving its integrity and independence), its guarantees cannot be undermined by militaristic considerations still permeating IHL according to many authors and practitioners.

\section{MOULDS OF JUS IN BELLO AND JUS AD BELLUM BROKEN BY NON-STATE ACTORS}

States are legal fictions, theoretical constructs that are tangible because of our belief in them. Yet, these social constructs exert influence in the lives of men, on which their presence, far from unreal, is felt. For these reasons, a disaggregated analysis of State behavior is necessary in order to fully comprehend the way in which law is implemented, especially international law, as a result of the inputs and interactions of multiple participants and actors.

Attaching excessive importance to the socio-legal construct that the State is, the international society has been analyzed from a highly fictional approach for a long time: even from a political science and historical perspective, State-centered paradigms were prevailing, in which the conduct of States alone and eventually and tangentially a few other actors were the ones primarily taken into account. However, recent studies have shown how this preconception blinded us from perceiving reality more fully: throughout history, even in the Westfalian system, many other actors have had a special relevance, influencing the way in which States act, and impacting the international society on their own alongside States. ${ }^{49}$ This makes me endorse the words of Myres McDougal, according to which ignorance of non-state actors is unrealistic. ${ }^{50}$

Unfortunately, the previous limitations were adopted by the internationallegal system, whose very name betrays the State-centrism that has pervaded it for long, reason why I prefer the coined term of jus gentium, encompassing both intra gentes and inter gentes dimensions. ${ }^{51}$ Human dignity protective norms have proven that this paradigm no longer endures lest the practice and normative consistency betray its limitations, but yet the reality of non-state actors is hardly grasped in its full by some international norms. This is the case, among others, of norms related to the use of force: those of jus ad bellum and those of jus in bello, comprising both humanitarian and human rights law, among other norms, unlike being reduced to the former, as is usually hinted.

\footnotetext{
${ }^{49}$ See Halliday, 'The Romance of Non-state Actors', in J. D. and W. Wallace (eds), Non-state Actors in World Politics (2001).

${ }^{50}$ See McDougal, 'The Realist Theory in Pyrrhic Victory', 49 American Journal of International Law (1955), at 377-378.

${ }^{51}$ On those dimensions, see A. Gómez Robledo, Fundadores del Derecho Internacional (Vitoria, Gentili, Suárez, Grocio)(1989), at 14-15, 98-99.
} 
In the case of those regimes, the State-centric mould is controversial due to its unrealism, making law lag behind reality and thus be unable to cope with crucial social problems, unlike what the maxim of sic societas sicut ius demands. Additionally, however, three sets of problems, dealing with very problematic issues arise as a result of its influence:

Firstly, gaps and deficits force practitioners and activists to resort to novel or constructive interpretations because law does not truly regulate situations in which regulation is needed: for example, in conventional law, the notion of transnational conflicts, to which the guarantees of common article 3 regarding non-international conflicts have been extended thanks to the practice of the ICRC and some States -the U.S.-, does not seem to be perfectly regulated in the aforementioned article due to its covering transnational situations -surpassing the territory of a single State-. .52

Secondly, the pervasive presence of non-state actors and their de facto impact on human dignity, make it necessary to regulate their behavior, lest they act unrestrained. In this sense, it is very telling that global governance and international relations theories have pointed out that regulation, both legal and non-legal, is necessary in order to control actors and make them adjust their behavior to certain standards, because norms have an expressive and educative function. ${ }^{53}$

Thirdly, lack of regulation, or outdated and insufficient rules that fail to tackle problems posed by nonstate actors, leave potential victims vulnerable and without access to remedies or protections in case State responsibility is not engaged. This problem has been highlighted by those that have put forward the idea that deeming it absolutely unlawful to allow for State protection of its inhabitants - which is a duty of the State- when non-state actors attack them from the territory of a State that is unable or unwilling to deal with those attacks can lead to injustices, in the material substantive sense of fairness. ${ }^{54}$ This mere example shows that the goals of protecting dignity and victims of war, which are the purposes of human rights law and humanitarian law respectively, ${ }^{55}$ cannot be fully achieved unless regulation takes account of the presence of non-state actors. And let us remember that the purposes of law should illuminate how norms are construed..$^{56}$

\footnotetext{
${ }^{52}$ The definitions provided for in Article 3.2 of the United Nations Convention against Transnational Organized crime provide an interesting and useful version of what crimes or offenses are "transnational in nature." It determines that an offense has that character if "(a) it is committed in more than one State; (b) It is committed in one State but a substantial part of its preparation, planning, direction or control takes place in another State; (c) It is committed in one State but involves an organized criminal group that engages in criminal activities in more than one State; or (d) It is committed in one State but has substantial effects in another State".

${ }^{53}$ See Goodman and Jinks, 'Incomplete Internalization and Compliance with Human Rights Law', 19 European Journal of International Law(2008), at 735; F. Halliday, op. cit., p. 35.

${ }^{54}$ I agree with Thomas Franck that procedural legitimacy is distinct from justice or material examinations or the fairness of law, although I disagree with some of his assertions regarding the latter. About his theory, see T. Franck, Fairness in International Law and Institutions (1998).

${ }^{55}$ See the Preamble and Articles 1, 22 and 23 of the Universal Declaration of Human Rights; C. Villán Durán, Curso de Derecho Internacional de los Derechos Humanos (2006), at 63, 92; Preamble to the Vienna Declaration and Programme of Action of the
} 
As a result of these ideas, in this article I carry out the task of shortly examining aspects of both jus in bello and jus ad bellum regarding non-state participation in attacks or armed conflicts.

\section{Jus ad bellum in the light of non-state attacks that amount to major uses of force.}

The General Assembly and the International Court of Justice recognized that non-state actors are capable of conducting attacks that have the same intensity of major uses of force, ${ }^{57}$ implicitly recognizing that they are able to commit minor uses of force as well. This possibility has been attested in practice on different occasions, and in many of them the attacks have been carried from within the territory of a State while targeting inhabitants of another State.

The reasons why this may happen are manifold: as judges Kooijmans and Simma considered, the existence of failed States -factual category- can be characterized by the absence of effective authorities capable of controlling the territory of that State, which permits non-state armed groups to operate unchecked and uncontrolled..$^{58}$ On the other hand, there are States that are operative to an acceptable degree and, yet, face the presence of non-state actors endowed with hard, soft or systemic power that enables them to challenge State authority. ${ }^{59} \mathrm{~A}$ third possibility, taken into account by U.N. Resolution 3314 (XXIX) of the U.N. General Assembly and the ICJ, alludes to the tolerance or even support by States of non-state armed groups that attack other States, allowing those groups to have sanctuaries on their territories or even going as far as supplying them with weapons

World Conference on Human Rights of 1993; Inter-American Commission on Human Rights, Report No. 112/10, Inter-State Petition IP-02, Admissibility, Franklin Guillermo Aisalla Molina, Ecuador - Colombia, 21 October 2010, par. 177; C. de Than and E. Shorts, International Criminal Law and Human Rights, Sweet \& Maxwell (ed), 2003, pp. 12-13; F. Kalshoven and L. Zegveld, Constraints on the Waging of War: An Introduction to International Humanitarian Law (2001), at 203-204.

${ }^{56}$ According to the technique of teleological interpretation. See, e.g., Article 31 of the Vienna Convention on the Law of Treaties; International Law Commission, "Conclusions of the work of the Study Group on the Fragmentation of International Law: Difficulties arising from the Diversification and Expansion of International Law”, $58^{\text {th }}$ session, 2006, A/61/10. Conclusions 13, 16, $21,27,29,30$.

${ }^{57}$ See International Court of Justice, Case concerning Military and Paramilitary Activities in and Against Nicaragua, Nicaragua v. United States of America, Judgment of 27 June 1986 (Merits), par. 195; article 3.g of Resolution 3314 (XXIX) of the General Assembly of the United Nations.

${ }^{58}$ See the Separate Opinions of Judges Kooijmans and Simma to the Judgment of 19 December 2005 of the International Court of Justice on the Case Concerning Armed Activities on the Territory of the Congo (Democratic Republic of the Congo v. Uganda), paragraphs 12 of the Opinion of Judge Simma and 30 of the Opinion of Judge Kooijmans.

${ }^{59}$ See del Arenal, 'La nueva sociedad mundial y las nuevas realidades internacionales: un reto para la teoría y para la política', in Cursos de Derecho Internacionaly Relaciones Internacionales de Vitoria-Gasteiz 2001 (2002) at 27-28, 34, 52-53, 64-66; Badia Martí, 'Cooperación internacional en la lucha contra la delincuencia organizada transnacional', in V. Abellán Honrubia and J. Bonet Pérez (eds), La incidencia de la mundialización en la formación y aplicación del Derecho Internacional Público, Los actores no estatales: ponencias y estudios (2008), at 319-320, 324, 336, 342; Galindo Vélez, 'Consideraciones sobre la determinación de la condición de refugiado', in S. Namihas (ed), Derecho Internacional de los Refugiados (2001) at 60-61; Lavenex, 'Globalization, Global Governance and the Bonnum Commune: a Conceptual Investigation', 6 European Journal of Law Reform (2004), p. 388 _vol.09, n. 02, Rio de Janeiro, 2016.pp. 980-1011 995 
or materials, actions which amount to contributions prohibited by norms of jus ad bellum, constituting minor uses of force. $^{60}$

Some States that face attacks attributable to non-state actors in this context have resorted to launching attacks against them in the territory of other States. Those that have had this practice are, among others, Turkey, Colombia, the United States, or Israel, and the Security Council seems to accept the lawfulness of those attacks in some situations, as will be explained below. Attacks of this kind are yet controversial, and have aroused doctrinal discussion. Some authors have sided with the States that have committed attacks against non-state groups in the conditions described thus far, considering that they have the right to self-defense in those situations, while others oppose this consideration. Apparently, this issue is unsettled and the uncertainty as to what the regulation permits is highly problematic, ever since it goes against the need of provision of certainty by law. ${ }^{61}$ In the light of this, I offer my humble interpretation of the legal issues atstake.

To my mind, the confusion is owed in part to the lack of clarity regarding which are the legal principles at stake. In this sense, most authors seem to consider that all attacks against non-state actors in the territory of a third State are to be analyzed in the light of the prohibition of the use of force, being it thus necessary to examine if the right of self-defense can extend to those attacks. I, however, consider that the prohibition of the use of force is the relevant norm only in some events, but certainly not in all of them. The OAS seems to endorse this opinion.

Let us begin by analyzing when the prohibition of the use of force against States is the norm at stake. Its regulation in article 51 of the U.N. Charter is certainly related to the prohibition of using force against third States, and according to this some regard that attacks against non-state groups operating from the territory of a third State entail, prima facie, a use of force against that State. This opinion is persuasive but not utterly convincing, because I hold that there are two events in which this is so, while in the remaining possibilities it is the principle of territorial integrity which is to be examined.

First of all, when the territorial third States have their responsibility engaged as a result of the behavior of non-state actors that amounts to major uses of force, and the attacks are directed against the non-state actor and agents or inhabitants of that State that do not belong to the non-state armed group, the territorial State is certainly the target of an attack. Likewise, when inhabitants of the territorial State not belonging to the non-state group are attacked alone, given the population of a State as one of its components and as comprising individuals that the State has the duty to protect - protection that justifies its powers- ${ }^{62}$ or when its territory is occupied or attacked

\footnotetext{
${ }^{60}$ See the first principle of Resolution 2625 (XXV) of the General Assembly of the United Nations.

${ }^{61}$ SeeJ.H.Jackson, Sovereignty, the WTOand Changing Fundamentals of InternationalLaw(2006), at 88-89, 148.

${ }^{62}$ See Articles 2 of the International Covenant on Civil and Political Rights, 1 of the American Convention on Human Rights, 1 of the European Convention for the Protection of Human Rights and Fundamental Freedoms, among others. Additionally, see Article I of the Inter-American Convention on Rights and Duties of States of 1933 states that "the state as a person of international law should possess [... ] a permanent population”; Concurring Opinion of Judge A.A. Cançado Trindade to the Advisory Opinion _vol.09, no. 02, Rio de Janeiro, 2016.pp.980-1011 996
} 
directly or disproportionately, i.e. when non-state armed actors are not the main target or attacks against them are disproportional taking into account territorial integrity, ${ }^{63}$ the territorial State can be deemed to beattacked too.

The previous reasons explain why in the Nicaragua or Congo versus Uganda cases the ICJ has considered that attacks attributable to defendant States to be examined in the light of the prohibition of the use of force: because the attacks were considered to be conducted against the territorial State as a result of their involvement in the operations of non-state armed groups. ${ }^{64}$ In those events, the conditions of article 51 of the U.N. Charter have to be met for attacks to be lawful under the right ofself-defense.

What happens, then, when the non-state group is the exclusive direct object of an attack, but the attack takes place in the territory of a third State? I consider that, in those cases, given the absence of an attack against another State, the prohibition of use of force in inter-state relations ${ }^{65}$ is not the proper norm with which compliance is to be examined. When examining an attack by the Colombian State against a Colombian guerrilla (FARC) in Ecuadorian territory, the OAS issued Resolution CP/RES. 930 (1632/08), where the importance of the territorial integrity of States was stressed. ${ }^{66}$ This, along with any absence of a mention of the right of self defense, even in order to dismiss claims to it, suggests that it was the principle of territorial integrity which was to be studied. I agree with this position, because the State is not under attack in those cases: certainly, its territory is the place where hostilities take place, but the specialized character of a norm dealing with the integrity of that territory is the one to be examined. In other words, among the principles of territorial integrity and the regulation of the use of force, the absence of a direct attack against a State and the fact that it is the respect of its territory which is infringed prima facie, mean that the specific norm dealing with the rights of the territorial State is the principle of territorial integrity. After all, States have rights both to not be attacked and to have their territory respected, ${ }^{67}$ both of which although interrelated guarantee different dimensions and rights.

Therefore, in those cases the presence of circumstances precluding wrongfulness is to be analyzed in connection with that territorial integrity, rather than employing the notion of inter-State self-defense. In this

OC-17/02 of the Inter-American Court of Human Rights, Juridical Condition and Human Rights of the Child, of 28 August 2002, par. 19.

${ }^{63}$ See the first principle of GA Res. 2625 (XXV); and article 3.a of GA Res. 3314 (XXIX); and Article I of the Inter-American Convention on Rights and Duties of States of 1933, that includes "a defined territory" as a component of States.

${ }^{64}$ See Waisberg, 'Colombia’s Use of Force in Ecuador Against a Terrorist Organization: International Law and the Use of Force Against Non-State Actors', 2 ASIL Insights (2008).

${ }^{65}$ See Article 2.4 of the Charter of the United Nations and GA Res. 2625 (XXV) and 3314 (XXIX).

${ }^{66}$ The Resolution decided to "reaffirm the principle that the territory of a state is inviolable and may not be the object, even temporarily, of military occupation or of other measures of force taken by another State, directly or indirectly, on any grounds whatsoever".

${ }^{67}$ See the fifth Principle of GA Res. 2625 (XXV), where it is mentioned that "[n]othing [... ] shall be construed as authorizing or encouraging any action which would dismember or impair, totally or in part, the territorial integrity $[\ldots]$ of sovereign and indepentend States conducting themselves in compliance with the principle of equal rights and self-determination of peoples [ ... ] and thus possessed of a government representing the whole people belonging to the territory without distinction as to race, creed or colour. Every State shall refrain from any action aimed at the partial or total disruption of the national unity and territorial integrity of any other State or country." 
regard, I consider that among others, Distress (see Article 24 of the ILC's Draft Articles on Responsibility of States for Internationally Wrongful Acts) may be applicable in some circumstances, but its stringent requirements must be met.

However, the fact that in some events no responsibility arises concerning the principle of territorial integrity does not automatically render actions against non-state groups lawful, because additionally the attack must meet the requirements of self-defense, although according to its customary content, rather than to its conventional content as regulated in the U.N. Charter, because as Philip Alston comments, some consider that the customary right of self-defense may be invoked against non-state actors, unlike that right as envisaged under the U.N. Charter. ${ }^{68}$ This is so because, as author Constantine Antonopoulos has argued, the conventional right of selfdefense as embodied therein seems to allude to inter-state uses of force and does not envisage uses of force against non-state actors, ever since article 51 is to be interpreted in connection with article 2.3, prohibiting inter-state uses of force, ${ }^{69}$ both of which belong to the U.N. framework and are to be interpreted systematically. ${ }^{70}$ Therefore, only when uses of force, even carried out by non-state actors, can be attributed to the State, the U.N. Charter would apply. Otherwise, it is necessary to determine whether the customary right of self-defense, which allows for its being invoked against non-state actors, is complied with.

What, then, is the customary regulation of self-defense against non-state actors, if it exists? According to various authors and judges, that right exists, as seems supported by practice of the Security Council, whose Resolutions 1368 (2001) and 1373 (2001) allude to one such right. ${ }^{71}$ Additionally, the opinio juris of that practice would rest on the assumption that States must have legal means with which to protect themselves and their inhabitants from non-state attacks somehow, when territorial States are unwilling or unable to counter non-state activities. The famous principle that sovereignty entails burdens, among which protection of the rights of third States is included -as asserted in the famous Island of Palmas case, decided by arbitrator Max Huber $-{ }^{72}$ seems to support this assertion.

\footnotetext{
${ }^{68}$ See Report of the Special Rapporteur on extrajudicial, summary or arbitrary executions, Philip Alston, Addendum, Study on Targeted Killings, A/HRC/14/24/Add.6, 28 May 2010, par.40.

${ }^{69}$ See Antonopoulos, "Force by Armed Groups as Armed Attack and the Broadening of Self-Defence", LV Netherlands InternationalLawReview(2008), at 163, 169.

${ }^{70}$ See Article 31 of the Vienna Convention on the Law of Treaties and International Law Commission, "Conclusions of the work of the Study Group on the Fragmentation of International Law: Difficulties arising from the Diversification and Expansion of International Law", 58 ${ }^{\text {th }}$ session, 2006, A/61/10. Conclusions 17-23.

${ }^{71}$ See the Preambles to SC Res. 1368 (2001) and SC Res. 1373 (2001); Report of the Special Rapporteur on extrajudicial, summary or arbitrary executions, Philip Alston, Addendum, Study on Targeted Killings, A/HRC/14/24/Add.6, 28 May 2010, par. 40.

${ }^{72}$ Max Huber commented therein that " $[t]$ erritorial sovereignty $[\ldots]$ involves the exclusive right to display the activities of a State. This right has a corollary duty: the obligation to protect within the territory the rights of other States, in particular their right to integrity and inviolability in peace and in war, together with the rights which each State may claim for its nationals in foreign territory." In Reports of International Arbitral Awards, Volume II, Island of Palmas case (Netherlands, USA), 4 April 1928.
} 
There is wide consensus among those that endorse this view that self-defense has to meet the same requirements of inter-State self-defense to be lawful, i.e. they must be proportional, necessary, respond to major uses of force, ${ }^{73}$ comply with the principle of temporality and respond to actual attacks, which means that preventive self-defense is unlawful, and only self-defense against imminent or actual attacks can be considered legal..$^{74}$

Discussions, however, are not pacific concerning an additional consideration: which attitude of the third territorial State is necessary for the possibility of lawfully invoking self-defense against non-state actors to be triggered? This is the point that proves to be the most difficult. Some authors regard that it is sufficient for the territorial State to be unable to deal with the non-state actors located in its territory, whereas others allude to the necessity of it being unwilling to do so. ${ }^{75}$ Other authors even apparently consider that any of these events justifies self-defense against non-state actors. ${ }^{76}$ This is the point whose resolution is the most difficult, ever since it is necessary to analyze which attitude of the territorial State can justify military operations in its territory as a last resort. Perhaps, as professor Cassese has commented vis-ì-vis a different issue related to the use of force, the evolution of practice oriented by a sense of what the legal regulation in these events should be may gradually evolve $^{77}$ and, thus, greater clarity may begiven.

Let it be said that, besides self-defense, attacks against non-state actors present in the territory of a third State are lawful when authorized by the Security Council as well. This is in accordance to the content of the (customary and conventional) regulation of the use of force, which has a peremptory character. ${ }^{78}$ It would be at least intriguing that those who espouse the recognition of this hierarchy simultaneously regard that the regulation

\footnotetext{
${ }^{73}$ On these requirements, see International Court of Justice, Case Concerning Oil Platforms, Islamic Republic of Iran v. United States of America, Judgment of 6 November 2003, pars. 43, 51, 64, 73-74,76-78.

${ }^{74}$ See A more secure world: Our shared responsibility, Report of the High-Level Panel on Threats, Challenges and Change, United Nations, 2004, pars. 188-192.

${ }^{75}$ Concerning this, Marko Milanovic mentioned that if "Article 51 does NOT require the attribution of the armed attack by a nonstate actor to a state $[\ldots]$ for the attacked state to respond against the non-state actor which is operating in another state, the conduct of this latter state must be such to justify the ensuing violation of its sovereignty. Various authors have proposed different standards, but three scenarios seem generally possible, on a scale from the most to the least stringent: (a) the territorial state was complicit or was actively supporting the non-state actor in its armed attack; (b) the territorial state failed to exercise due diligence, i.e. it did not do all that it could reasonably have done to prevent the non-state actor from using its territory to mount an armed attack against another state, or is not doing all it can to prevent further attacks; (c) the territorial state may have exercised due diligence, but it was nonetheless unable to prevent the attack, or to prevent further attacks. The US post-9/11 invasion of Afghanistan could be quite comfortably justified under these standards." In: Milanovic, 'Self-Defense and Non-State Actors: Indeterminacy and the Jus ad Bellu', EJIL: Talk!, 2010, available on: http://www.ejiltalk.org/self-defense-and-non-state-actorsindeterminacy-and-the-jus-ad-bellum/

${ }^{76}$ See Waisberg, op. cit., who claims that "State practice and the UN Security Council's actions after the September 11 attacks may, however, indicate a trend towards recognizing that a State that suffers large-scale violence perpetrated by non-State actors located in another State has a right to use force in self-defense when (1) that other State proves unwilling or unable to reduce or eliminate the source of the violence".

77 See Cassese, 'Ex iniuria ius oritur: Are We Moving towards International Legitimation of Forcible Humanitarian Countermeasuresinthe WorldCommunity?,10 EuropeanJournalofInternationalLaw(1999), at27,29-30.

${ }^{78}$ See A. Gómez Robledo, Ellus Cogens Internacional: Estudiohistórico-crítico(2003), at 156-157, 159-160, 167.
} _vol.09, no. 02, Rio de Janeiro, 2016.pp. 980-1011 
of the use of force admits exceptions, namely self-defense and authorization by the Security Council, ever since peremptory norms are characterized precisely by their being absolute. ${ }^{79}$ Therefore, self-defense and Security Council authorization are part of the content of the regulation of the use of force, rather than exceptions to it.

Finally, let it be said that some authors consider that authorizing self-defense against non-state actors may lead to anarchy and intensification of hostilities worldwide. The opposite position, however, would permit perpetuation of unchecked attacks against inhabitants of States due to territorial States and non-state actors relying on the impossibility of means available to a State to protect the affected individuals. Let it be said in this connection that, besides being unfair, this would foster impunity, because absence of measures against violations of human dignity -which can be committed by non-state attacks- foster repetition of those conducts, as has been ascertained by the Inter-American Court of Human Rights. ${ }^{80}$ Naturally, this does not translate into endorsing every State reaction, ever since only when serious attacks have been committed and there are no alternative means, self-defense against non-state actors that impinges upon the territorial integrity of another State would be authorized by law, as long as they are conducted in accordance with criteria of proportionality, necessity and humanity, among others.

\section{Jus in bello challenges posed by non-state actors' participation in hostilities.}

As mentioned above, there are uncertainties surrounding the legal regulation of the right to resort to force against non-state actors, owed in part to the lack of express codifications on the matter given the international paradigm of the jus gentium legal system that to a great degree still lags behind a reality where multiple non-state actors are rampart and exert influence on the legal system and the global society. ${ }^{81}$ This, however, does not equate to saying that law is absolutely silent on those issues, and undoubtedly non-state actors

\footnotetext{
${ }^{79}$ As follows from their description in Article 53 of the Vienna Convention on the Law of Treaties. Given that instrument's aim of regulating agreements that are treaties, the characterization of peremptory norms as norms that admit no derogation -which hints to agreements or norms against jus cogens- must be interpreted in the sense that this hints to the non-admissibility of any exceptions whatsoever to the effectiveness, display of effects and primacy of jus cogens.

${ }^{80}$ The Inter-American Court of Human Rights has considered that toleration of a human rights violation, which is not properly dealt with by law, "reproduces the conditions of impunity for [that] type of facts to happen again". See: Inter-American Court of Human Rights, Case of the "Mapiripán Massacre” v. Colombia,Judgment ofSeptember 15, 2005, par. 238.

${ }^{81}$ See, among others, Pérez-Prat Durbán, 'Actores no estatales en la creación y aplicación del Derecho Internacional', in V. Abellán Honrubia and J. Bonet Pérez (eds), La incidencia de la mundialización en la formación y aplicación del Derecho Internacional Público: los actores no estatales: ponencias y estudios (2008); Gatto, 'Corporate Social Responsibility in the External Relations of the EU', in 24 Yearbook of European Law (2005); Halliday, op. cit.; Reinisch, 'The Changing International Legal Framework for Dealing with Non-State Actors', in P. Alston (ed), Non-State Actors and Human Rights (2005), at 53, 68, 77; A. Clapham, Human Rights Obligations of Non-State Actors, (2006); Bianchi, 'Globalization of Human Rights: The Role of Non-state Actors', in G. Teubner (ed), Global Law Without a State, (1997); Buergenthal, 'The Evolving International Human Rights System', 100 American Journalof International Law (2006), at 804; A. Bianchi, op. cit.,pp. 189-190.
} 
are taken into account by customary law, which besides having a life independent from its conventional counterpart ${ }^{82}$ proves to be more dynamic than treaty law in some events, ${ }^{83}$ as in the ones being explained.

Simultaneously, the impact of non-state actors that employ armed force during armed conflicts is to be reflected in the regulation of the conduct of hostilities during armed conflicts, i.e. concerning the jus in bello. And this is so because absence of regulation of non-state conduct may encourage and seem to endorse their abuses, while enacting norms that regulate their behavior in these and other situations may change their perspective and attitude, due to acculturation and interiorization processes, ${ }^{84}$ besides exposing those actors to shaming and condemnation when they fail to abide by standards imposed onthem.

When the expression jus in bello is used, it is usually employed in the understanding that it comprises the law of the Hague and the law of Geneva or, in other words, (contemporary) international humanitarian law, which regulates the conduct of hostilities by parties to armed conflicts. ${ }^{85} \mathrm{I}$, however, consider that the expression also accommodates other norms that are applicable during armed conflicts, because the fact that they do not cease to have effects in those events entails that they continue to bind and regulate the behavior of at least some parties to the conflict. In this sense, it is certainly important to note that human rights law is applicable both in times of peace and of war. ${ }^{86}$

I will limit my study to some features of IHL and human rights law in this article, bearing in mind that other norms, such as those on the law of refugees or international criminal law, are equally applicable and may form part of the jus in bello, which also comprises secondary or derived rules, as some issued by the Security Council, that may place obligations on combatants even if they are non-state actors ${ }^{87}$. Let me comment one more thing regarding the jus in bello: its applicability is not dependent upon the lawfulness of prior attacks or, in other words, compliance with jus ad bellum. ${ }^{88}$ As a result, whether self-defense or collective security operations duly

\footnotetext{
${ }^{82}$ See International Court of Justice, Case concerning Military and Paramilitary Activities in and Against Nicaragua, Nicaragua v. United States of America, Judgment of 27 June 1986 (Merits), pars. 174-179.

${ }^{83}$ See Ramelli Arteaga, 'La Corte Constitucional colombiana como intérprete de las costumbres internacionales', Estudio de Derecho Internacional Humanitario Consuetudinario: Memorias delevento de presentación, Bogotá - Colombia, marzo 7 de $2008(2009)$, at 19.

${ }^{84}$ See Goodman and Jinks, op. cit.; Koh, 'Why Do Nations Obey International Law?', 106 Yale L.J.(1997).

${ }^{85}$ See F. Kalshoven and L. Zegveld, op. cit., pp. 15-16.

${ }^{86}$ See International Court of Justice, Legal Consequences of the Construction of a Wall in the Occupied Palestinian Territory, Advisory Opinion of 9 July 2004, par. 105; Hans-Joachim Heintze, "On the relationship between human rights law protection and international humanitarian law", International Review of the Red Cross, No. 856, 2004. Additionally, it has been said that "everyone is entitled to the enjoyment of human rights, whether in time of peace or war", as commented in Office of the High Commissioner for Human Rights, Fact Sheet No. 13, International Humanitarian Law and Human Rights. The Inter-American Commission on Human Rights, in its report No. 112/10 went on to clearly declare how human rights are enjoyed by individuals even during armed conflict, and that those rights are even contained in the branch of humanitarian law. See Inter-American Commission on Human Rights, Report No. 112/10, Inter-State Petition IP-02, Admissibility, Franklin Guillermo Aisalla Molina, Ecuador - Colombia, 21 October 2010, pars. 116-126.

${ }^{87}$ See International Court of Justice, Accordance with International Law of the Unilateral Declaration of Independence in respect of Kosovo, Advisory Opinion, 22 July 2010, pars. 115-116.

${ }^{88}$ See F. Kalshoven and L. Zegveld, op. cit., at84.
} 
authorized by the Security Council are conducted or not, the conduct of those who take part in hostilities must abide by the jus in bello. Human rights law has a peculiar dilemma: is it applicable to non-state actors? This, however, will be studied shortly.

When it comes to international humanitarian law, it seems settled that the norms of this branch, as part of the international legal system, can impose duties on non-state armed groups, as Theodor Meron or Andrew Clapham acknowledge, ${ }^{89}$ and Common Article 3 of the 1949 Geneva Conventions, along with their Additional Protocols I and II confirm. Nonetheless, as conventional norms, their application is dependent on the condition that the territorial State in which hostilities where those actors participate are conducted, or the State that fights against those actors, is a party to those treaties. The provisions of Additional Protocol I, on their part, are applicable to some non-state armed groups in as long as they emit a declaration pursuant to article 96.3 of that instrument, ${ }^{90}$ while Additional Protocol II is effective insofar as the conditions of article 1, regarding the elements of noninternational armed conflicts that trigger the applicability of that instrument, ${ }^{91}$ are met. Of those norms, it is common article 3 which is less demanding, because it neither requires declarations of acceptance of the non-state groups nor a non-international armed conflict to present some specific features. Therefore, IHL treaty law may seem insufficient to address non-state behavior in the context being studied because it may either be inapplicable or, if applicable, it can be too vague or limited in scope, as is the case when only common Article 3 regulates the behavior of non-state actors. Customary law applicable to non-international armed conflicts does not present the aforementioned limitations, but the question ensues which conflicts are comprised in that category. This will be studied shortly.

Conventional IHL, therefore does not escape to the challenges posed by non-state actors to norms devised under the consideration that international law was -supposedly- mostly concerned with regulating interstate behavior. One other such challenge is that of what kind of armed conflict corresponds to those armed confrontations with the intensity that surpasses the threshold for them to be considered armed conflicts when

\footnotetext{
${ }^{89}$ See T. Meron, The Humanization of International Law (2006), at 40; A. Clapham, op. cit., at 73.

${ }^{90}$ According to that provision, "The authority representing a people engaged against a High Contracting Party in an armed conflict [in which peoples are fighting against colonial domination and alien occupation and against racist regimes in the exercise of their right of self-determination] may undertake to apply the Conventions and this Protocol in relation to that conflict by means of a unilateral declaration addressed to the depositary. Such declaration shall, upon its receipt by the depositary, have in relation to that conflict the following effects: ( a ) The Conventions and this Protocol are brought into force for the said authority as a Party to the conflict with immediate effect; ( b ) The said authority assumes the same rights and obligations as those which have been assumed by a High Contracting Party to the Conventions and this Protocol; and ( c ) The Conventions and this Protocol are equally binding upon all Parties to the conflict."

${ }^{91}$ Those conditions are the following: for Protocol II to be applicable, the conflict must "take place in the territory of a High Contracting Party between its armed forces and dissident armed forces or other organized armed groups which, under responsible command, exercise such control over a part of its territory as to enable them to carry out sustained and concerted military operations and to implement this Protocol." Therefore, besides ruling out transnational conflicts, or conflicts between non-state actors, non-state parties to the conflict must have some conditions for the Protocol to have effects that are not required for common article 3 to apply to these and other non-international armed conflicts.
} 
they, however, are conducted between parties at least some of which are non-state actors and have a transnational character, in the sense that they surpass the territory of a single State. Naturally, those conflicts would not be international armed conflicts, ever since they do not involve the confrontation of States amongthemselves. ${ }^{92}$

On the other hand, however, at first glance it seems as if common article 3 would not be applicable either, because that provision seems to stress the idea of a conflict taking place within the territory of a State. ${ }^{93}$ This problem has been acknowledged by the ICRC and, as Marko Milanovic comments, has led that organization to extend the guarantees of non-international armed conflicts to these transnational armed conflicts in practice, stretching the applicability of conventional international humanitarian law. ${ }^{94}$ This extension is more than welcome and necessary, because guarantees, rights and duties that protect the victims of war are necessary and imperative. However, in my opinion unlike common article 3, currently the category of non-international armed conflicts in customary law clearly comprises both transnational and national non-international armed confrontations, thus being it impossible to consider that this exercise is creative -although creativeness would be necessary otherwise, as the law of human dignity and its peremptory norms demand-.

Let it be further said that the practice of some States, such as the United States of America -through its Supreme Court-, endorse the idea that common article 3 makes IHL applicable in transnational armed conflicts. ${ }^{95}$ To my mind, the assertion made by Marko Milanovic that the problems may be solved when considering that it is not necessary to stretch common article 3 but, rather, that it can be considered that customary international humanitarian law regulating non-international armed conflicts does not know the geographical limitations of common article $3,{ }^{96}$ proves to be very persuasive.

Concerning international human rights law, let me begin by reminding that it is applicable in times of war and does not cease to produce effects when IHL comes into play. That States are bound by their norms is a given, but when it comes to non-state actors, let the following be said: besides doctrinal, codification, progressive development and jurisprudential discussions that show how nothing prevents international norms, even those of human rights law, from placing obligations upon any actor as long as they respect jus cogens and are produced in accordance with the sources of international law, ${ }^{97}$ there is an underlying assumption in the decisions of international bodies: from a factual point of view, non-state actors are capable of injuring human beings and attacking the content and enjoyment of human rights. This is recognized by mentions of the destruction or abuse

\footnotetext{
${ }^{92}$ Common Article 2 to the Geneva Conventions of 1949.

${ }^{93}$ That article states that it is applicable "In the case of armed conflict not of an international character occurring in the territory of one of the High Contracting Parties" (emphasisadded).

${ }^{94}$ See Milanovic, 'Lessons for human rights and humanitarian law in the war on terror: comparing Hamdan and the Israeli Targeted Killingscase', 89 International ReviewoftheRed Cross, No.866(2007), at381.

${ }^{95}$ Ibid., pp. 377-381.

${ }^{96}$ See Ibid., p. 381.

${ }^{97}$ See A. Clapham, op. cit.,pp.70-73.
} 
of human rights at the hands of non-state actors, ${ }^{98}$ and by the idea that positive duties of States under the horizontal effects of human rights presuppose that the actions of non-state entities against which protection must be granted are human rights violations, as declared by the Inter-American Court of Human Rights. ${ }^{99}$

As a result, two tasks must be undertaken: firstly, it is necessary to create de lege ferenda obligations of non-state armed entities in order to prevent their injuring human dignity, the foundation of human rights law. Secondly, interpretation of existing law must be made in a way that acknowledges that those human rights that have the status of jus cogens norms and can be factually violated by non-state actors impose an implied duty of abstaining from abusing those rights (duty of respect) on those actors. This has been intuitively handled, and in fact there has been international criminal prosecution of torture against individuals (who are non-state actors) for committing or aiding in the commission of this crime that is also a human rights abuse and a violation of IHL. ${ }^{100}$ Additionally, as the European Court of Human Rights ruled in the Kononov case, customary law may place jus in bello obligations on non-state actors (individuals) directly, even in the absence of conventional or domestic norms imposing a duty with the same content. ${ }^{101}$

To my mind, implied duties of non-state actors for the sake of the effectiveness of peremptory norms that protect human dignity are founded on the basis that those norms allow no exceptions whatsoever, including exceptions in the form of interpretations that non-state entities are not bound by them which would deprive peremptory norms of their effective and all-encompassing normative -and factual-supremacy. It must be clarified, yet, that while criminal law sanctions some human rights violations ${ }^{102}$ and could thereby be considered the other side of the coin of peremptory human rights law, it is more accurately just another of the many sides of the die of human dignity protection, which admits more responses to non-state violations and by any potential offender.

In fact, the finding that human rights are found in and protected by some humanitarian and criminal norms ${ }^{103}$, inter alia, and the sanction of violations of those human rights against non-state actors when committed in times or armed conflicts by non-state entities, supports these conclusions.

\footnotetext{
${ }^{98}$ See I. BANTEKAS, I. and S. NASH, International Criminal Law, (2003), at 14; Dufresne, Review of: Liesbeth Zegveld, The Accountabilityof Armed Opposition Groupsin International Law, 15 European Journal of International Law (2004), at227.

${ }^{99}$ The Inter-American Court of Human Rights has considered that "States must prevent, investigate and punish any violation of the rights recognized by the Convention and, moreover, if possible attempt to restore the right violated and provide compensation as warranted for damages resulting from the violation [... ] An illegal act which violates human rights and which is initially not directly imputable to a State (for example, because it is the act of a private person or because the person responsible has not been identified) can lead to international responsibility of the State, not because of the act itself, but because of the lack of due diligence to prevent the violation or to respond to it as required by the Convention" (emphasis added). In Inter-American Court of Human Rights, Case of Velásquez-Rodríguezv. Honduras,Judgment ofJuly29, 1988 (Merits),par. 172.

${ }^{100}$ See International Tribunal for the Prosecution of Persons Responsible for Serious Violations of International Humanitarian Law Committed in the Territory of the Former Yugoslavia since 1991, Prosecutor v. Anto Furundzija, Judgement, 10 December 1998, par. 147, 153-157,159.

${ }^{101}$ See European Court of Human Rights, Case of Kononovv. Latvia,Judgment of 17 May 2010, pars. 207-208, 213,227,236-239.

${ }^{102}$ See C. de Than and E. Shorts, op. cit., pp. 12-13.

${ }^{103}$ Ibid.
} 
The previous consideration that different branches, such as IHL and human rights law, are interlinked, leads us to the widely commented connection between those formal branches. Most of the time it has been considered by International Courts -e.g. the ICJ or the Inter-American Court of Human Rights- that during armed conflicts some human rights are to be interpreted in the light of IHL, given the latter's eventual condition of lex specialis in the regulation of armed conflicts. ${ }^{104}$ While this is so in many cases, given the more detailed and specialized regulation during armed conflicts that IHL provides sometimes, that it is not always the case.

Concerning this, when they do not conflict with each other, given their simultaneous applicability, ${ }^{105}$ at least four alternative situations have been commented upon. First of all, as Philip Alston has suggested, human rights law should not be deferent with IHL when hostilities are not being conducted ${ }^{106}$ : in those events, even within the broader framework or context of an armed conflict, affirming a specialized character of IHL would be impertinent, given the specialized character of human rights incomparison.

Secondly, as Marko Milanovic and the Inter-American Commission on Human Rights have considered, in some events it is precisely human rights law which is more specialized and detailed than IHL, ${ }^{107}$ and given the latter's inclusion of human rights, broadness and vagueness in such events, it must be interpreted in the light of human rights law, as its lex specialis.

Thirdly, as follows from a judgment of the Israeli Supreme Court, human rights law may limit international humanitarian law in some events, thus protecting the guarantees of the protection of human dignity more strongly than do the often sad norms of IHL, ${ }^{108}$ given the importance of military necessity for them. ${ }^{109}$

Lastly, according to the International Court of Justice, it is very accurately deemed that IHL and human rights law have, besides intersections, spheres in which they are not interrelated ${ }^{110}$ and thus in them no interpretation according to the criterion of lex specialis is warranted but both spheres would apply on their own.

\footnotetext{
${ }^{104}$ See Inter-American Commission on Human Rights, Report No. 112/10, Inter-State Petition IP-02, Admissibility, Franklin Guillermo Aisalla Molina, Ecuador - Colombia, 21 October 2010, pars. 120-122, 124; International Court of Justice, Legal Consequences of the Construction of a Wall in the Occupied Palestinian Territory, Advisory Opinion of 9 July 2004, pars. 105106.

${ }^{105}$ See Report of the Special Rapporteur on extrajudicial, summary or arbitrary executions, Philip Alston, Addendum, Study on Targeted Killings, A/HRC/14/24/Add.6, 28 May 2010, par. 29, footnote53.

${ }^{106}$ See Ibid., where the Rapporteur comments that "In situations that do not involve the conduct of hostilities - e.g., law enforcement operations during non-international armed conflict - the lex generalis of human rights law would apply".

${ }^{107}$ See Inter-American Commission on Human Rights, Report No. 112/10, Inter-State Petition IP-02, Admissibility, Franklin Guillermo Aisalla Molina, Ecuador - Colombia, 21 October 2010, par. 121; Marko Milanovic, "Lessons for human rights and humanitarian law in the war on terror: comparing Hamdan and the Israeli Targeted Killingscase", at 391.

${ }^{108}$ See Milanovic, "Lessons for human rights and humanitarian law in the war on terror: comparing Hamdan and the Israeli Targeted Killingscase”, op. cit., at 390-392.

${ }^{109}$ See F. Kalshoven and L. Zegveld, op. cit., at 37-38,203-204.

${ }^{110}$ See International Court of Justice, Legal Consequences of the Construction of a Wall in the Occupied Palestinian Territory, Advisory Opinion of 9 July 2004, par. 106.
} 
In conclusion, rather than IHL being automatically lex specialis during armed conflicts, the mutual relations, cross-fertilization and exchanges between all norms belonging to the jus ad bellum ${ }^{111}$ must be considered in the light of factual circumstances on a case by case basis.

Human rights law has another problem when transnational armed conflicts are ongoing: is it applicable extraterritorially when States conduct operations abroad? According to the ICJ, the Human Rights Committee and the Inter-American Commission on Human Rights, at least, it seems that it does, given the control and/or power of State agents over individuals. ${ }^{112}$ The jurisprudence of the European Court of Human Rights, on its part, is too limited because of its emphasis on territorial control, rather than acknowledging that it is State power or control, even absent territorial control, which impacts on the lives of human beings. In cases such as Issa v. Turkey it considered that overall effective control of a territory amounts to the controlling State having jurisdiction, ${ }^{113}$ while in the -for some- (in)famous Bankovic case it denied this possibility on the basis that this sort of power alone not coupled with certain territorial control does not always equate with the notion of individuals being under the jurisdiction of a State that is required for human rights obligations to bind it, because accepting this would admit a causal finding of jurisdiction and making the European Convention applicable worldwide. ${ }^{114} \mathrm{To}$ my mind, this argument conceals a hidden fallacy ever since the applicability of the Convention should not be studied from a Euro-territorial perspective but from a Euro-presence approach, which makes it potentially applicable worldwide even since it would bind Parties to it everywhere where they have power -control-over the rights of individuals and impact on their enjoyment.

I admit that I agree with the point of view of those who accept the extraterritorial application of human rights law in these events, for otherwise States may elude their duties due to formalities -not devoid of controversy- and further their questionable actions with double-standards.

${ }^{111}$ On these relations, see Inter-American Commission on Human Rights, Report No. 112/10, Inter-State Petition IP-02, Admissibility, Franklin Guillermo Aisalla Molina, Ecuador-Colombia, 21 October 2010, par. 121.

${ }^{112}$ See Ibid., pars. 87-103.

${ }^{113}$ See European Court of Human Rights, Case of Issa and Others v. Turkey, Judgment, 16 November 2004, pars. 68-71, where it was considered that "[i]n exceptional circumstances the acts of Contracting States performed outside their territory or which produce effects there ("extra-territorial act") may amount to exercise by them of their jurisdiction within the meaning of Article 1 of the Convention [... According to the relevant principles of international law, a State's responsibility may be engaged where, as a consequence of military action - whether lawful or unlawful - that State in practice exercises effective control of an area situated outside its national territory. The obligation to secure, in such an area, the rights and freedoms set out in the Convention derives from the fact of such control, whether it be exercised directly, through its armed forces, or through a subordinate local administration $[\ldots]$ It is not necessary to determine whether a Contracting Party actually exercises detailed control over the policies and actions of the authorities in the area situated outside its national territory, since even overall control of the area may engage the responsibility of the Contracting Party concerned [... ] Moreover, a State may also be held accountable for violation of the Convention rights and freedoms of persons who are in the territory of another State but who are found to be under the former State's authority and control through its agents operating - whether lawfully or unlawfully - in the latter State $[\ldots]$ Accountability in such situations stems from the fact that Article 1 of the Convention cannot be interpreted so as to allow a State party to perpetrate violations of the Convention on the territory of another State, which it could not perpetrate on its own territory" (emphasis added). ${ }^{114}$ See European Court of Human Rights, Decision as to the Admissibility of Application No. 52207/99, 12 December 2001, pars. $61,75-81$. 
Another issue related to the participation of non-state actors in armed conflicts is that of the direct participation of civilians in hostilities. As conventional and customary IHL state, civilians cannot be lawfully the direct object of an attack unless and as long as they directly participate in hostilities. ${ }^{115}$ While members of nonstate armed groups and these groups themselves are clearly non-state actors, the condition of those individuals belonging to the armed forces of a non-state entity is unclear as to whether they are civilians or not, which is certainly problematic. ${ }^{116}$ This problem has to do with the question of whether they may be targeted even when not taking part in armed activities in the case that they have ongoing combat operations within non-state armed groups. The same question applies to members of security companies with continuous combat functions operating during armed conflicts, who may or not be civilians, ever since their performance of acts considered to amount to direct participation in hostilities in accordance with the instructions given to them and their continuous functions may make them members of an armed party to a conflict, either formally or de facto, or they may even become independent parties to an armed conflict, in the opinion of theICRC. ${ }^{117}$

Regarding the question of their being targeted, according to a report issued by the ICRC, individuals with an ongoing or continuous combat function in an armed group lose their civilian status and become combatants, and hence can be targeted at any time when belonging to non-state armed groups or operating on their own. Otherwise, if an individual does not participate in hostilities for a party to them in accordance with a continuous combat function and is thus not a combatant, he is a civilian and can only be lawfully targeted by parties to an armed conflict during his direct participation in hostilities ${ }^{118}$

Concerning this opinion, Philip Alston has voiced his concerns and disagreement with the notion of continuous or ongoing combat functions, because he thinks that it may be contrary to the temporal limit on the possibility of attacking civilians put forth in the norms that permit these attacks in as long as civilians participate directly in hostilities, which would be ignored by this doctrine. ${ }^{119}$ The Study on customary international law conducted by the ICRC, however, points out that ignoring this continuity of combat functions may create an

\footnotetext{
${ }^{115}$ See Rule 6 of the Customary IHL Database of the ICRC, based on the Study on customary international humanitarian law conducted by the ICRC, regarding "Civilians' Loss of Protection from Attack", available on http://www.icrc.org/customaryihl/eng/docs/vl_rul_rule6; Articles 13.3 of Protocol II and 51 of Protocol I to the Geneva Conventions of 1949, relating to the Protection of Victims of Non-International Armed Conflicts and the Protection of Victims of International Armed Conflicts, respectively.

${ }^{116}$ See Recommendation II of the ICRC's Interpretive Guidance on the Notion of Direct Participation in Hostilities under International Humanitarian Law, 2009, p. 16; Rule 5 of the Customary IHL Database of the ICRC, based on the Study on customary international humanitarian law conducted by the ICRC, dealing with the "Definition of Civilians", available on http://www.icrc.org/customary-ihl/eng/docs/v1_rul_rule5

${ }^{117}$ See Recommendation III of the ICRC's Interpretive Guidance on the Notion of Direct Participation in Hostilities under International Humanitarian Law,2009, p. 16; and its Commentary, pp.39-40

${ }^{118}$ See Recommendations VI and VII of the ICRC's Interpretive Guidance on the Notion of Direct Participation in Hostilities under International Humanitarian Law, 2009, p. 17.

${ }^{119}$ See Report of the Special Rapporteur on extrajudicial, summary or arbitrary executions, Philip Alston, Addendum, Study on Targeted Killings, A/HRC/14/24/Add.6, 28 May 2010, par.65.
} 
imbalance between State and non-state combatants. ${ }^{120}$ It is not discussed, in any case, that during actual participation they may be targeted, and that this participation must have a clear direct link with combat and the capacity to consciously cause direct damage to a party to the conflict with a certain intensity, ${ }^{121}$ which almost always for example discards considering that supplying armed materials to combatants amounts to direct participation. ${ }^{122}$

Regarding the operation of private security companies, let it be said that, as doctrine has rightly considered, they can be mercenaries if they meet the requirements of article 47 of Additional Protocol I to the Geneva Conventions, whose content is reflected in customary law applicable to international armed conflicts, ${ }^{123}$ and it is considered that mercenaries cannot enjoy the status of prisoners of war in non-international armed conflicts, where it does not exist. ${ }^{124}$ Apart from this, the problem of their participation is twofold, at least: they may give the opportunity to States that hire them to circumvent democratic controls and checks concerning the waging of war and, additionally, their being mainly profit-oriented may distort practice and lead them to attach little or no importance to peace by overvaluing the money they get. ${ }^{125}$ This, coupled with the phenomenon of the detachment and lack of empathy that can surround attacks carried out by these and other individuals from a computer and far from the battlefield, ${ }^{126}$ is at least risky and worrisome.

Finally, let it be reminded that the jus ad bellum considerations are irrelevant when analyzing if parties to an armed conflict are bound by the jus in bello, because even if an attack is lawful, actions in its context may be illegal. Likewise, it seems that an unlawful use of force -violation of the jus ad bellum- does not automatically render actions of combatants belonging to the party to whom those uses are attributable unlawful: they are regulated by the independent jus in bello. The fact that, for instance, the crime of aggression is independent of war crimes, the crime of genocide and crimes against humanity, ${ }^{127}$ seems to support this consideration: both can be violated simultaneously, but this is not necessarily so all the times.

\footnotetext{
${ }^{120}$ See Rule 6 of the Customary IHL Database of the ICRC, based on the Study on customary international humanitarian law conducted by the ICRC, regarding "Civilians' Loss of Protection from Attack".

${ }^{121}$ The detailed conditions that, in opinion of the ICRC, make an act direct participation in hostilities are put forth in: Recommendations IV and V of the ICRC's Interpretive Guidance on the Notion of Direct Participation in Hostilities under International Humanitarian Law, 2009, pp. 16-17.

${ }^{122}$ Ibid., pp. 11, 34-35, 51-53

${ }^{123}$ See Rule 108 of the Customary IHL Database of the ICRC, based on the Study on customary international humanitarian law conducted by the ICRC, dealing with "Mercenaries", available on http://www.icrc.org/customary-ihl/eng/docs/vl_rul_rule108 ${ }^{124}$ Ibid.

${ }^{125}$ See Salzman, 'Private Military Contractors and the Taint of a Mercenary Reputation', 40 New York University Journal of InternationalLawandPolitics(2008), at866-874.

${ }^{126}$ As can be inferred from: Report of the Special Rapporteur on extrajudicial, summary or arbitrary executions, Philip Alston, Addendum, Study on Targeted Killings, A/HRC/14/24/Add.6, 28 May 2010, par. 84.

${ }^{127}$ See Rome Statute of the International Criminal Court, Article 5. Likewise, this is hinted by the distinction between crimes against peace, crimes against humanity and war crimes found in Principle VI of the Principles of International Law Recognized in the Charter of the Nürnberg Tribunal and in the Judgment of the Tribunal or in Article 6 of the Charter of the International
} __vol.09, nº. 02, Rio de Janeiro, 2016. pp. 980-1011 


\section{CONCLUSIONS}

As explored in this article, contemporary dynamics pose risks of excessive uses of force. Firstly, there is a risk of a temptation to exaggerate regarding what lethal attacks are permitted. As pointed out above, there is a connection between peace and human rights, as highlighted by the links between the duties and role of the Security Council and these rights and as expressly mentioned by the human rights Committee. It is self-evident that during armed conflicts life is constantly at risk, and so to my mind legal interpretation and practice cannot continue to endorse the possibility of IHL being taken advantage of in order to permit abusive entities to tweak its norms and treat individuals as their means, disregarding their dignity and placing State or non-state interests, often selfish, ${ }^{128}$ over truly humanitarian considerations. Otherwise, we would be going backwards and ignoring that international law has been progressing towards its humanization, although we must not be blinded believing that this process has come to an end ${ }^{129}$ but rather identify possible gaps and points to which attention must be given, such as the one being studied in this article.

Even if the premises and ideas expounded in this text are not agreed with, it cannot be denied that a militaristic mindset still pervades IHL and that following it may put lives at risk or even encouraging resorting to war, something that must be discouraged in order to try to generate a new attitude towards resorting to war and respecting human dignity. In fact, IHL was successful in modifying the behavior of non-state actors to a certain extent in the past, ${ }^{130}$ so if the arguments presented herein are considered not to be lex lata, then at least de lege ferenda their adoption may contribute to human dignity and human rights considerations being prevalent and always present, thus being it possible to employ them in order to shame States and non-state actors that kill during

\footnotetext{
Military Tribunal - Annex to the Agreement for the prosecution and punishment of the major war criminals of the European Axis (“London Agreement).

${ }^{128}$ On the existence of State selfish interests, see Rafael Domingo, op. cit,, at 139; Celestino Del Arenal, "La nueva sociedad mundial y las nuevas realidades internacionales: un reto para la teoría y para la política", in Cursos de Derecho Internacional y Relaciones Internacionales de Vitoria-Gasteiz 2001, Bilbao, 2002, at 29. Noam Chomsky has considered, for instance, that "states are not moral agents. They act in their own interests. And that means the interests of powerful forces within them", as seen in: http://www.chomsky.info/interviews/200105--htm. Non-state actors may share this negative trait of selfishness, because both types of actors are composed of and operate through human beings, as a disaggregated analysis of them will show. Concerning the disaggregated analysis, see Eric A. Posner, The Perils of Global Legalism, The University of Chicago Press, 2009, at 40-42; Thomas M. Franck, "Individuals and Groups of Individuals as Subjects of International Law", in Rainer Hofmann (ed.), Non-State Actors as New Subjects of International Law, Duncker \& Humblot (ed.), 1999, at 112.

${ }^{129}$ See Concurring opinion of judge A. A. Cançado Trindade to the Advisory Opinion on the Juridical Condition and Rights of Undocumented Migrants of the Inter-American Court of Human Rights, OC-18 of 17 September 2003, paras. 25, 27, 88; Rafael Domingo, op. cit..

${ }^{130}$ See Fred Halliday, "The Romance of Non-state Actors", in Daphné Josselin and William Wallace (eds.), Non-state Actors in World Politics, Palgrave (ed.),2001, at35.
} 
"unjust wars" and to hold them responsible, aiming to generate a new dynamic in which recourse to force is not treated lightly and the respect life is truly treated as supreme. ${ }^{131}$

As mentioned before, none of this aims to prevent multi-lateral authorizations of force or self-defense when they are necessary to protect civilian populations, but it must not be forgotten that human rights considerations should also bind the Security Council, that is not to be a limitless entity but must behave in accordance to the rule of law, ${ }^{132}$ being necessary for it to consider human rightslaw. ${ }^{133}$

Additionally, it is important to say that the blurring of the borders between jus ad bellum and jus in bello proposed here do not entail their disappearance. This is to be avoided because, as has been pointed out, this disappearance could prevent imposing limits on the conduct of all parties to hostilities (if jus ad bellum prevailed) or the eventual impossibility of charging an entity with violating the prohibition of the use of force (if jus in bello prevailed) ${ }^{134}$ However, an absolute hermetic separation also runs the risk of legitimating violations of human dignity, and thus adoption of the middle path of blurring the boundaries is advisable.

On the other hand there is the problem of non-state conduct that has the same intensity as State major uses of force, which can evidently dramatically affect individuals. The global legal good ${ }^{135}$ of security and peace is not only threatened when it reaches international dimensions: every disturbance to this legal good is of the concern of the global community even when it takes place within the confines of a single country, as attested by efforts by the international community to deal with internal conflicts, regulated by its norms.

Globalization has reinforced the power of some non-state actors, thus making more evident problems that however already existed or were potential before. The need to protect individuals in armed conflicts and from the actions of non-state armed actors makes it necessary to adjust our legal understanding and practice in order to be able to fully provide the protection of human dignity that every individual deserves given her/his inner worth, which is not conditional.

Sometimes, this protection can be granted by adjusting our interpretation of existing norms regulating the jus ad bellum and the jus in bello. However, in other events law must change de lege ferenda. Customarily,

\footnotetext{
${ }^{131}$ See Human Rights Committee, Article 6 (Right to life), General comment No. 6, Sixteenth session, 1982, para. 1; Human Rights Committee, Article 6 (Right to life), General comment No. 14, Twenty-third session, 1984, para. 1.

${ }^{132}$ See Janne Elisabeth Nijman, 'Non-State Actors and the International Rule of Law: Revisiting the 'Realist Theory' of International Legal Personality”, Amsterdam Center for International Law Research Paper Series, 2009 at 2, 7-19, available on: http://papers.ssrn.com/sol3/papers.cfm?abstract_id $=1522520$

${ }^{133}$ For this analysis, it is useful to ascertain what the role of human rights law within the United Nations framework is, because the Security Council is empowered by it and is equally limited by it given its implicit duties and rule of law considerations. On implicit duties of international bodies and organizations, see Koen de Feyter, "Globalisation and human rights", in Felipe Gómez Isa and Koen de Feyter (eds.), International Human Rights Law in a Global Context, 2009, at 70. Concerning the role of human rights in the United Nations framework, see Felipe Gómez Isa, "International Protection of Human Rights", in Felipe Gómez Isa and Koen De Feyter (eds.), International Protection of Human Rights: Achievements and Challenges, University of Deusto, 2006, at 26-32. ${ }^{134}$ This insight is offered in: Frits Kalshoven and Liesbeth Zegveld, op. cit., at 84.

${ }^{135}$ An explanation of what global legal goods are is offered in: http://papers.ssrn.com/sol3/papers.cfm?abstract_id=1753036
} _vol.09, nº. 02, Rio de Janeiro, 2016.pp. $980-1011$ 
sometimes it has changed so, but much more work, studies, progressive development and advocacy are needed in order to clearly and fully protect human beings universally, i.e. not only everywhere but from everyone, and to adapt law to the social context and needs presentcurrently.

Trabalhoenviadoem 13deabrilde2016. Aceito em 03 de maio de 2016. 